\title{
Different effects of feeding pregnant and lactating mice Rhodiola kirilowii aqueous and hydro-alcoholic extracts on their serum angiogenic activity and content of selected polyphenols
}

\author{
ROBERT ZDANOWSKI ${ }^{1}$, EWA SKOPIŃSKA-RÓŻEWSKA ${ }^{2,3}$, JACEK WILCZAK ${ }^{4}$, ANNA BORECKA ${ }^{5}$, \\ ANETA LEWICKA ${ }^{6}$, SEAWOMIR LEWICKI ${ }^{I}$ \\ 'Department of Regenerative Medicine and Cell Biology, Military Institute of Hygiene and Epidemiology, Warsaw, Poland \\ ${ }^{2}$ Department of Microwave Safety, Military Institute of Hygiene and Epidemiology, Warsaw, Poland \\ ${ }^{3}$ Pathomorphology Department, Center for Biostructure Research, Warsaw Medical University, Warsaw, Poland \\ ${ }^{4}$ Department of Physiological Sciences Faculty of Veterinary Medicine Warsaw University of Life Sciences, Warsaw, Poland \\ ${ }^{5}$ Laboratory of Parasitology, Military Institute of Hygiene and Epidemiology, Warsaw, Poland \\ ${ }^{6}$ Laboratory of Food and Nutrition Hygiene, Military Institute of Hygiene and Epidemiology, Warsaw, Poland
}

\begin{abstract}
Angiogenesis plays an important role in many physiological processes, among them the formation of tissues and organs during embryogenesis. A lot of medicinal plants exhibit angiomodulatory properties. This creates the need for a thorough check of whether the plant extracts that we would like to give to pregnant women in order to increase their resistance to bacterial or viral infection will have negative effects on angiogenesis, and consequently on fetal development. This paper seeks to investigate the effect of serum of pregnant and nursing Balb/c mice that received aqueous $(R K W)$ or hydro-alcoholic $(R K W$-A) R. kirilowii extracts $(20 \mathrm{mg} / \mathrm{kg})$, or epigallocatechin $(0.2 \mathrm{mg} / \mathrm{kg})$, on the in vitro proliferation and migration of mouse endothelial cell line HECa10. Of the 15 identified polyphenols in the extracts by HPLC, 8 were present in the sera. Chemical analysis revealed higher salidroside, kaempferol, chlorogenic acid, $b F G F$ and VEGF concentration in $R K W-A$ sera than in the sera of $R K W$ group of mice. $R K W-A$ and EGC sera did not affect migration of endothelial cells, however we noted some increase of migrating cells after $R K W$-sera treatment. RKW and EGC sera did not affect proliferation of endothelial cells. Sera of mothers from $R K W$-A group impaired the proliferation of endothelial cells in comparison to other groups. These data allow us to assume that Rhodiola kirilowii hydro-alcoholic extract $(R K W-A)$ is potentially able to modulate pre-and post-natal angiogenesis what might influence the development of organs in progeny. Sera of $R K W$ mothers have not harm the proliferation of endothelial cells, despite they also contain antiangiogenic catechins and salidroside. This suggests the existence in $R K W-A$ extract and in $R K W-A$ sera of some other, as yet unidentified substances influencing endothelial cells proliferation.
\end{abstract}

Key words: mice, pregnancy, Rhodiola kirilowii, polyphenols, angiogenesis.

(Cent Eur J Immunol 2017; 42 (1): 17-23)

\section{Introduction}

Angiogenesis is the formation of new blood vessels on the basis of those already existing. It is an important part of many phenomena and physiological responses, and together with vasculogenesis is driving the development of tissues and organs during embryonic and fetal life. So, one may expect that remedies containing anti-angiogenic substances might be unsafe in pregnancy $[1,2]$.

Plants of the Rhodiola genus have been used for centuries in Eastern medicine as adaptogens and anti-inflammatory drugs, and in our previous studies they presented immunomodulatory properties [3-8]. Despite their beneficial properties Rhodiola species were not recommended for use

Correspondence: Sławomir Lewicki Department of Regenerative Medicine and Cell Biology, Military Institute of Hygiene and Epidemiology, Kozielska 4, 01-163, Warsaw, Poland, e-mail: lewickis@gmail.com Submitted: 20.10.2016; Accepted: 28.10.2016 
during pregnancy and lactation, due to a lack of research into their impact on embryonic angiogenesis.

Our studies on these plants ( $R$. rosea, $R$. quadrifida and $R$. kirilowii) showed inhibitory effect of their hydro-alcoholic extracts on tumor angiogenesis [9-11].

However, in studies completed in 2012, we discovered that aqueous extract of roots of Rhodiola kirilowii (stimulating a number of parameters of cellular immunity in mice), did not inhibit L1 sarcoma neovascularization [11]. We could not be sure, of course, if it will not have deletorious effect on fetal development and the health of the offspring of mice fed the extract during pregnancy, because the processes of tumor and fetal angiogenesis do not always run in parallel, and, moreover, the extract contains some potentially anti-angiogenic substances belonging to the group of polyphenols. Then, we decided to see what will be the impact of feeding pregnant mice aqueous and hydro-alcoholic extracts of Rhodiola kirilowii on the angiogenic activity and selected polyphenols content of their sera. We also conducted a determination of proangiogenic growth factors, VEGF and bFGF.

\section{Material and methods}

\section{Preparation and analysis of Rhodiola extracts}

The roots and rhizomes of Rhodiola kirilowii were collected from field cultivations of Institute of Natural Fibers and Medicinal Plants. The raw material was washed, cut into thick slices, dried in natural conditions and next powdered. Aqueous extract: finely powdered roots were extracted two times with water (extraction was performed: first -2 hour and second -1 hour long, in the ratio raw material/solvent $1 / 5)$, in the temperature of $40^{\circ}-45^{\circ} \mathrm{C}$. The supernatants were mixed together and after centrifugation at $3000 \mathrm{rpm}$ for 15 min were lyophilized. Hydroalcoholic extract: finely powdered roots were extracted with ethanol/water solution (1/1, $\mathrm{v} / \mathrm{v}$, in the ratio raw material/solvent $1 / 10$ ) by the percolation method. Then the percolates were lyophilized (preceded by the distilling off the ethanol in the temperature $40^{\circ}-45^{\circ} \mathrm{C}$ ). Extracts were stored at $-70^{\circ} \mathrm{C}$ until further use.

Chemical analysis of extracts was done as previously described [1, 12]. Total extract polyphenols/flavonoids concentration $(16.16 \mu \mathrm{g} / \mathrm{mg}$ and $23.75 \mu \mathrm{g} / \mathrm{mg}$ in RKW and RKW-A, respectively) was assayed by applying the HPLC system (Dionex) equipped in the CoulArray electrochemical detector (ESA Inc.). The content of individual chemical compounds in a dry mass of extract was presented as mean $\mu \mathrm{g} / \mathrm{mg} \pm \mathrm{SEM}$ (mean of 3 independent experiments).

\section{Epigallocatechin}

Epigallocatechin (EGC) was purchased from Sigma Aldrich (Warsaw, Poland, cat. no: E3768-5MG), dissolved in distilled water and stored at $-70^{\circ} \mathrm{C}$ until used.

\section{Animals}

Experiments were performed on the adult inbred female Balb/c mice (Mossakowski Medical Research Centre Polish Academy of Sciences), 8-9 weeks old, 20-22 g b.m., mated with adult males from the same strain. Females, since copulatory plug was noted, up to the 28-th day after delivery were fed daily with dissolved in distilled water, lyophilized RKW or RKW-A extract (20 mg/kg b.m). This dose corresponds to a dose of $100 \mathrm{mg}(1.6 \mathrm{mg} / \mathrm{kg})$ given to a person weighing $60 \mathrm{~kg}$ with accordance to Shin et al. [13] mouse/human converter. Another group of female mice were supplemented with epigallocatechin (EGC) $0.2 \mathrm{mg} / \mathrm{kg} \mathrm{b.m}$. The daily dose of EGC match the total content of epicatechin, epigallocatechin, epicatechin gallate and epigallocatechin gallate present in 400 micrograms (daily dose) of RKW-A extract. Control mothers received the distilled water. Females were housed separately and to avoid stress connected with handling and gavage, tested substances were applied on a corn crisp, and served to the mice in a Petri dish. Control mice received distilled water applied on a corn crisp. On the 28-th day after delivery, mothers were anesthetized, bled and sacrificed. For all performed experiments animals were handled according to the Polish regulation concerning the wellness of laboratory animals (Polish National Institute of Health) standards. All experiments were accepted and conducted according to ethical guidance of Local Bioethical Committee, (permission 73/2011). Mice were maintained under conventional conditions (room temperature $22.5-23.0^{\circ} \mathrm{C}$, relative humidity 50-70\%, $12 \mathrm{~h}$ day/night cycle) with free access to breeding rodent feed (Labofeed H, Wytwornia Pasz "Morawski") and water.

\section{Serum}

Mice were bled in anaesthesia (intraperitoneal injection of ketamine $120 \mathrm{mg} / \mathrm{kg}$ of b.w. and xylazine $12 \mathrm{mg} / \mathrm{kg}$ of b.w. solution) from retro-orbital plexus. Sera were separated by 1-hour clotting (RT), centrifuged at $2000 \times g$ for 20 min and stored at $-70^{\circ} \mathrm{C}$ until analysis.

\section{HPLC analysis of serum}

Total serum polyphenol/flavonoids concentration from the sera of mothers was assayed by applying the HPLC system (Dionex) equipped with the CoulArray electrochemical detector (ESA Inc). The extraction procedure of polyphenols/flavonoids was performed as described previously [1, 12]. The results are presented as mean $\mathrm{ng} / \mathrm{ml} \pm \mathrm{SEM}$.

\section{Measurement of growth factors concentration}

The levels of VEGF and bFGF in sera were determined by ELISA tests (R\&D Systems) according to the producer's protocols. The results are presented as mean $\mathrm{pg} / \mathrm{ml} \pm \mathrm{SEM}$.

\section{Endothelial cell culture}

HECa10 mouse endothelial cell line was kindly provided by Professor Claudine Kieda from the Centre of Mo- 
lecular Biophysics, Orléans, France. The murine HECa10 cell line obtained from endothelial cells of the mouse peripheral lymph nodes immortalized by transfection of plasmid with the gene for the large $\mathrm{T}$ antigen of Simian virus 40 was used in the experiments $[14,15]$. Typical endothelial features of HECa10 mouse endothelial cell line, such as the presence of angiotensin-converting enzyme, von Willebrand factor, VE-cadherin, and the intracellular E-selectin, are preserved [15]. Cells were maintained in 75 $\mathrm{cm}^{2}$ (Becton Dickinson Falcon) culture flasks under standard culture conditions $\left(5 \% \mathrm{CO}_{2}, 37^{\circ} \mathrm{C}, 95 \%\right.$ R.H. $)$ with medium renewal every 2-3 days.

\section{Proliferation assay}

Proliferation of endothelial cells was estimated using AlamarBlue ${ }^{\circledR}$ (resazurin), a dye that measures the metabolic activity of living cells.

AlamarBlue assay was performed as described previously $[16,17]$ with some modifications. Briefly, the cells (in log phase growth stage) were harvested (Accutase PAA), centrifuged, suspended in culture medium (DMEM, $4.5 \mathrm{~g}$ / $\mathrm{ml}$ glucose with L-glutamine, $10 \%$ tested mother-mouse serum, $50 \mathrm{U} / \mathrm{ml}$ penicillin, $50 \mu \mathrm{g} / \mathrm{ml}$ streptomycin), to the final density of $0.5 \times 10^{5}$ cells $/ \mathrm{ml}$ and seeded into a 96-well plate $(100 \mu \mathrm{l}$ per well). Next, the plates were incubated at standard culture conditions of $5 \% \mathrm{CO}_{2}$ in air at $37^{\circ} \mathrm{C}$. Twenty-four hours later the culture medium was discarded and fresh culture medium with $10 \%$ of tested mother-mouse serum and AlamarBlue (1 : 10 PAA) was added directly to the wells. Fluorescence (excitation $544 \mathrm{~nm}$ and emission $590 \mathrm{~nm}$ ) was measured directly in the wells after $24 \mathrm{~h}$ incubation using FLUOstar Omega reader (BMG Labtech).

\section{Migration assay}

Migration assays were performed on cells in log phase growth stage as previously described [17]. Briefly, the cells were harvested, centrifuged, suspended in medium with the addition of $10 \mu \mathrm{g} / \mathrm{ml}$ DilC12(3) fluorescent dye (Becton
Dickinson) and stained 1 hour in standard condition. Next, cells were harvested, centrifuged and suspended in FBS free culture medium to the final density $8 \times 10^{5}$ cell $/ \mathrm{ml}$. $250 \mu \mathrm{l}$ of the prepared cells suspension $\left(2 \times 10^{5}\right.$ cell $)$ was added on the $3 \mu \mathrm{m}$ FluoroBlok inserts (Becton Dickinson) and placed in 24-well plate. Chambers under the inserts were filled with $750 \mu \mathrm{l}$ of culture medium (DMEM with $10 \%$ addition of mothers-mice sera). As negative control serum-free culture medium was used. After $24 \mathrm{~h}$ incubation in standard conditions $\left(37^{\circ} \mathrm{C}, 5 \% \mathrm{CO}_{2}\right)$, the inserts were relocated into new 24-well plate containing $1 \mathrm{ml}$ of PBS and the fluorescence was measured directly in the plate with inserts (excitation $549 \mathrm{~nm}$ emission $565 \mathrm{~nm}$ ) using the reader with bottom optic option. The results were presented as relative fluorescence units - RFU (mean \pm SEM).

\section{Statistical analysis}

Statistical evaluation of the results obtained in the control and experimental groups was done using unpaired $t$ test and one-way ANOVA (in the case of a normal distribution) or non-parametric Kruskal-Wallis test (in the case of abnormal distribution). Assessment of normal distribution of data was evaluated by Shapiro-Wilk test (GraphPad Software, Inc., San Diego, USA).

\section{Results}

\section{Phenolic compounds present in sera of mice}

In serum of all mice-mothers (regardless of studied group) we did not notice the presence of naringenin, luteolin, p-coumaric and ferulic acid. Salidroside as well as kaempferol were found only in serum of mice from RKW and RKW-A groups, wherein concentration of both compounds was higher in RKW-A group (Fig. 1B). Interestingly fisetin was noted only in control group. The highest concentration of quercetin was found in control $(5.32 \mathrm{ng} /$ $\mathrm{ml}$ of serum) and the lowest in EGC group $(3.50 \mathrm{ng} / \mathrm{ml}$ of serum). Curiously we have recorded higher concentration

Table 1. HPLC analysis of mothers sera. Mean concentration (ng/ml \pm SEM ) polyphenols/flavonoids in the sera of mice-mothers. Statistical differences between RKW and RKW-A sera: salidroside $p=0.03$, kaempferol $p=0.0652$ (on the border of significance), (+)-catechin and epicatechin $p=0.001$. Unpaired $t$ test

\begin{tabular}{lccccccccc}
\hline & Salidroside & Fisetin & Kaempferol & Ellagic acid & Quercetin & Chlorogenic acid & $(+)$-catechin & EC & EGC \\
\hline $\begin{array}{l}\text { Control } \\
(n=8)\end{array}$ & Not found & $0.51 \pm 0.06$ & Not found & $2.51 \pm 0.21$ & $5.32 \pm 0.46$ & $0.62 \pm 0.03$ & $3.36 \pm 0.27$ & $0.62 \pm 0.14$ & $0.55 \pm 0.08$ \\
\hline $\begin{array}{l}\text { RKW } \\
(n=8)\end{array}$ & $2.26 \pm 0.43$ & Not found & $3.16 \pm 0.29$ & $2.07 \pm 0.18$ & $4.29 \pm 0.38$ & $0.47 \pm 0.04$ & $4.39 \pm 0.44$ & $1.11 \pm 0.18$ & $0.59 \pm 0.08$ \\
\hline $\begin{array}{l}\text { RKW-A } \\
(n=11)\end{array}$ & $4.02 \pm 0.14$ & Not found & $4.20 \pm 0.44$ & $1.76 \pm 0.08^{*}$ & $4.46 \pm 0.40$ & $1.26 \pm 0.38$ & $2.03 \pm 0.16^{*}$ & $1.90 \pm 0.06^{*}$ & $0.28 \pm 0.08$ \\
\hline $\begin{array}{l}\text { EGC } \\
(n=8)\end{array}$ & Not found & Not found & Not found & Not found & $3.50 \pm 0.25$ & $0.26 \pm 0.05^{* * *}$ & $2.79 \pm 0.26$ & $\begin{array}{c}5.36 \\
\pm 0.45^{* * *}\end{array}$ & $\begin{array}{l}1.57 \\
\pm 0.05^{* *}\end{array}$ \\
\hline
\end{tabular}

Differences from the control: $* p<0.05, * * p<0.01, * * * p<0.001$

EC-epicatechin; EGC - epigallocatechin; $R K W$ - aqueous extract $R$. kirilowii; $R K W-A-50 \%$ hydro-alcoholic extract $R$. kirilowii 
A Polyphenolic compounds in RKW and RKW-A extracts

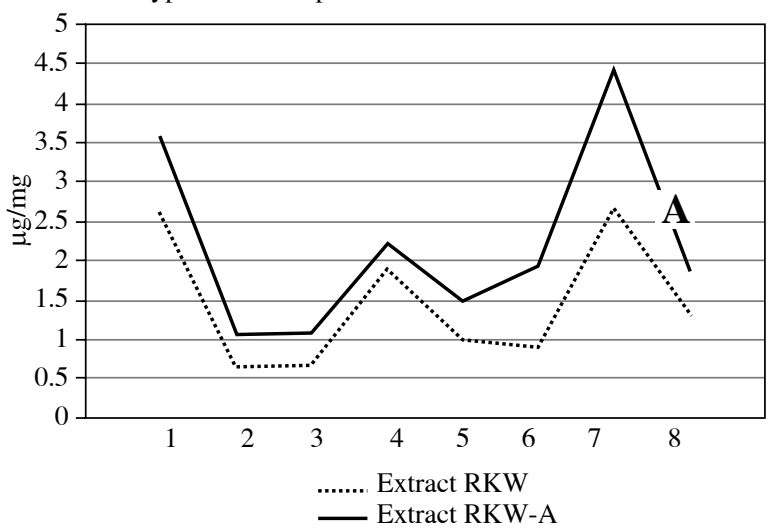

B

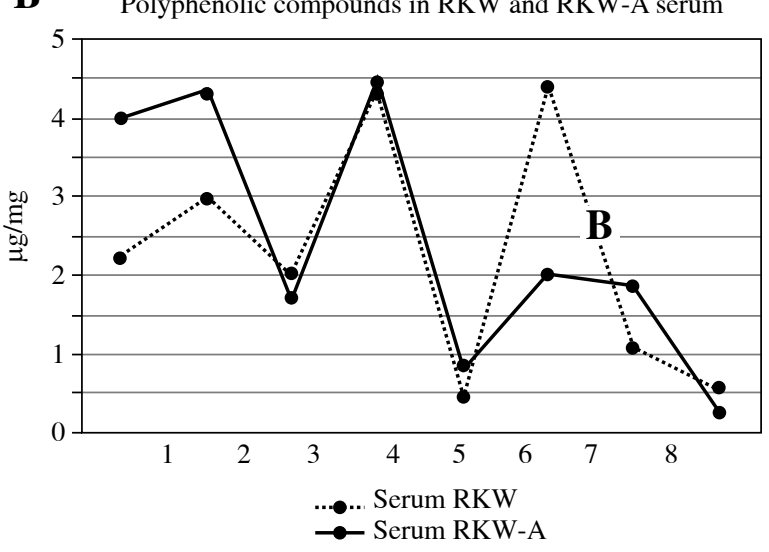

Fig. 1. A) HPLC analysis of extracts. Statistical differences between RKW and RKW-A extracts: salidroside (1) $p<0.05$, kaempferol (2) $p<0.001$, ellagic acid (3) $p<0.001$, quercetin (4) $p<0.01$; chlorogenic acid (5), (+)-catechin (6), epicatechin (7), epigallocatechin (8): $p<0.0001$. Unpaired t test. B) HPLC analysis of mothers sera. Statistical differences between RKW and RKW-A sera: salidroside (1) $p=0.03$, kaempferol (2) $p=0.0652$ (on the border of significance), (+)-catechin (6) and epicatechin (7) $p=0.001$. Unpaired $t$ test
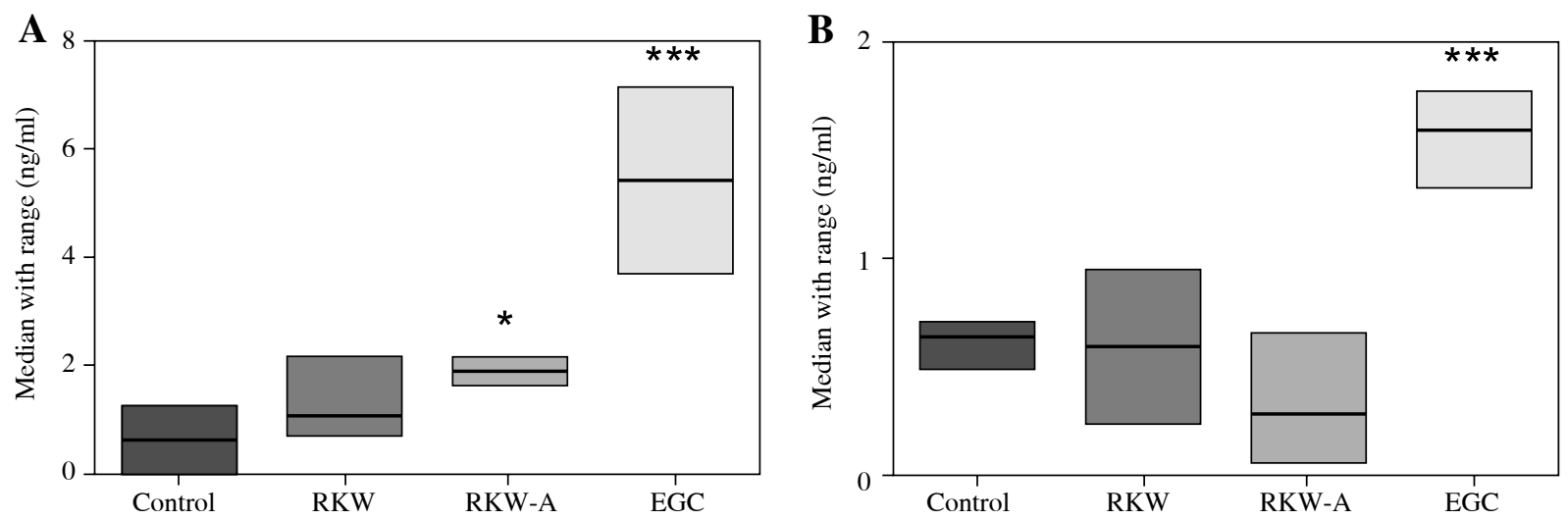

$* p<0.05, * * * p<0.001$. Total number of analyzed sera: 35 . Kruskall-Wallis test

Fig. 2. Median concentration with min-max range (ng/ml) of epicatechin (A) and epigallocatechin (B) in sera of mice-mothers

of (+)-catechin in RKW than in RKW-A group of sera, despite the fact that concentration of this polyphenol in RKW-A extract was almost twice as high than in RKW extract. Described results are presented in Table 1 and on Fig. 1A and Fig. 1B.

Serum analysis of epicatechin and epigallocatechin revealed the highest concentration of both polyphenols in EGC group ( $p<0.001$, Fig. 2). It has not been observed differences between control, RKW and RKW-A groups except epicatechin level which was significantly increased in RKW-A group.

\section{Discussion}

Flavonoids represent a wide group of more than 4000 secondary plant metabolites. Food-derived flavonols (quer- cetin and kaemferol) and flavanols (tannins and catechins) have been reported to exhibit various biological functions, including antioxidant, anti-inflammatory, antimicrobial, anticancer, cardioprotective, neuroprotective, antidiabetic, antiosteoporotic, estrogenic/antiestrogenic, anxiolytic, analgesic and anti-allergic activities [18].

Our studies revealed the presence of salidroside and kaempferol in the sera of mothers belonging to RKW and RKW-A groups, wherein concentration of salidroside was significantly higher in RKW-A mothers sera, than in sera of mothers from RKW group. These substances are also present in other plants of the Rhodiola genus, e.g. Rhodiola sachalinensis and Rhodiola rosea [19]. Sera examined in the present study contained catechins and phenolic acids also. However, comparing various polyphenols/flavonoids content in extracts and in mother mice sera we did not 


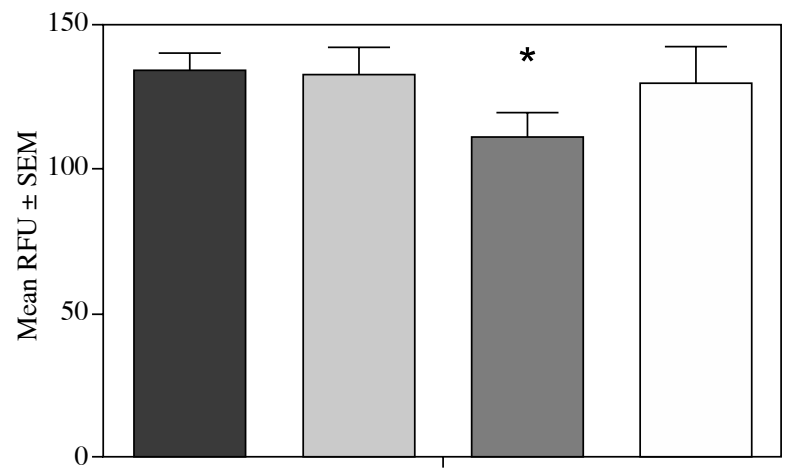

\begin{tabular}{|c|c|}
\hline Unpaired $t$ test & \\
\hline$p$ value & 0.0326 \\
\hline$p$ value summary & $*$ \\
\hline Are means sinif. different $(p<0.05)$ & Yes \\
\hline One- or two-tailed $p$ value? & Two-tailed \\
\hline$t, \mathrm{df}$ & $t=2.296, \mathrm{df}=20$ \\
\hline
\end{tabular}

$\square$ Control sera (11) $\quad \square$ RKW-A sera (11)

$\square$ RKW sera (11) $\quad \square$ EGC sera (7)

Fig. 3. Proliferation of endothelial HECa10 cells in the presence of sera from: control mothers, mothers fed R. kirilowii aqueous extract (RKW), hydro-alcoholic extract (RKW-A), or epigallocatechin (EGC). Number of mice in parentheses

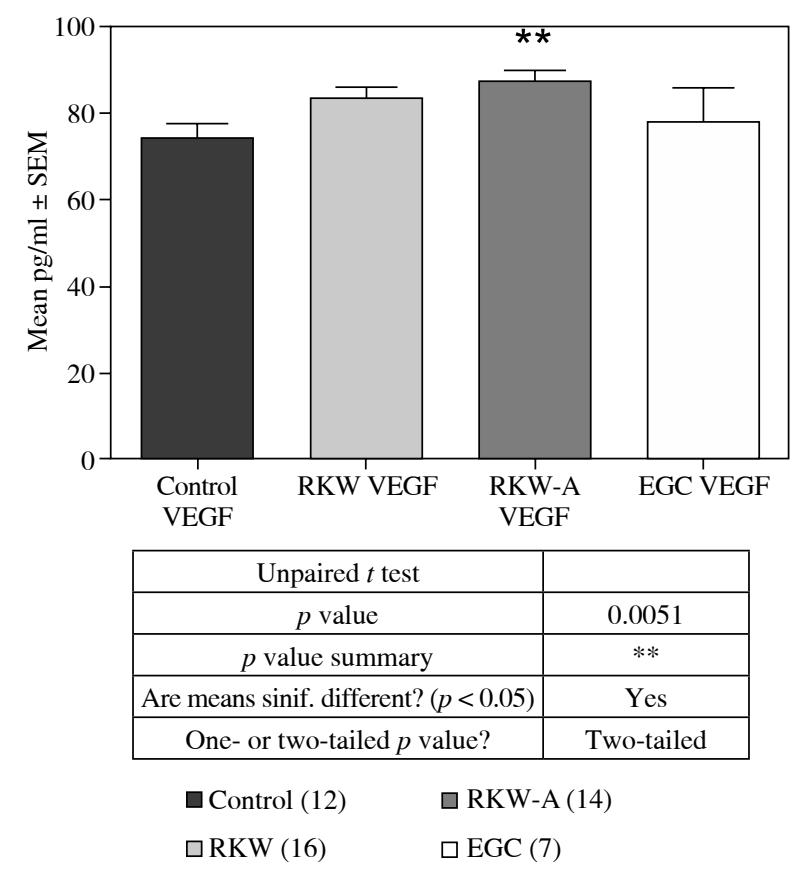

Fig. 5. VEGF concentration in the sera from: control mothers, mothers fed $R$. kirilowii aqueous extract (RKW), hydro-alcoholic extract (RKW-A), or epigallocatechin (EGC). Number of mice in parentheses

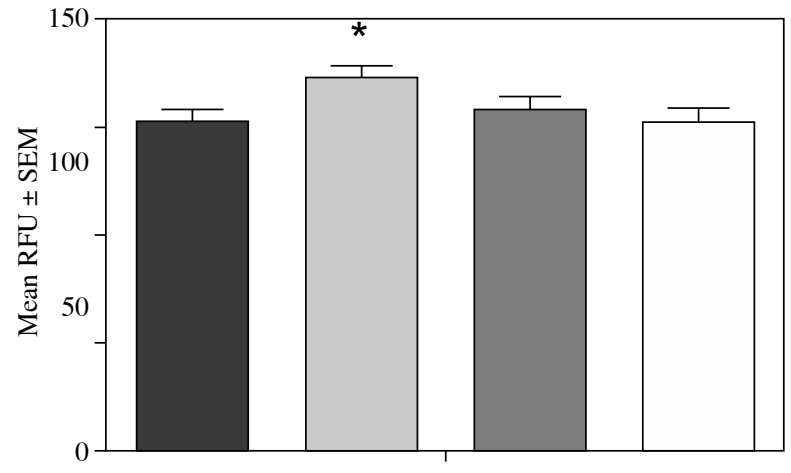

\begin{tabular}{|c|c|}
\hline One-way analysis of variance & \\
\hline$p$ value & 0.0573 \\
\hline$p$ value summary & $\mathrm{ns}$ \\
\hline Are means sinif. different? $(p<0.05)$ & No \\
\hline Number of groups & 4 \\
\hline $\mathrm{F}$ & 2.689 \\
\hline$r^{2}$ & 0.1492 \\
\hline Control sera (11) $\quad \square$ RKW-A sera (11) \\
$\square$ RKW sera (11) $\quad \square$ EGC sera (7)
\end{tabular}

Fig. 4. Migration of endothelial HECa10 cells in the presence of sera from: control mothers, mothers fed $R$. kirilowii aqueous extract (RKW), hydro-alcoholic extract (RKW-A), or epigallocatechin (EGC). Number of mice in parentheses

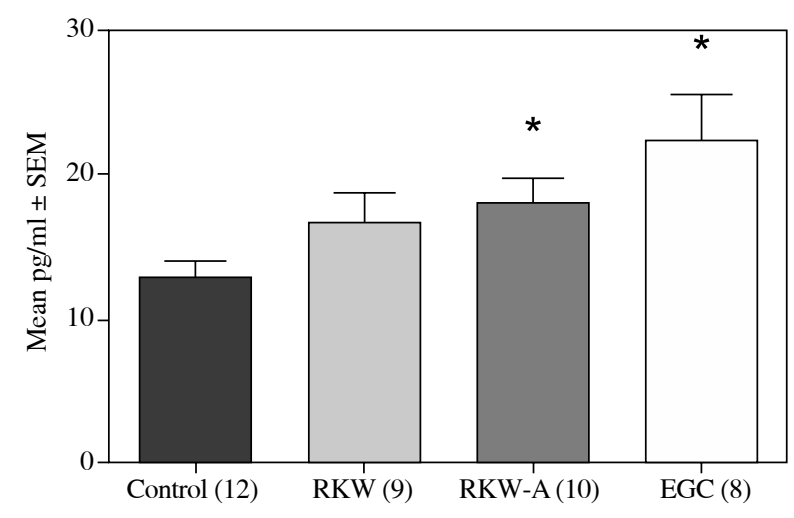

\begin{tabular}{|c|c|}
\hline Unpaired $t$ test & \\
\hline$p$ value & 0.0198 \\
\hline$p$ value summary & $*$ \\
\hline Are means sinif. different? $(p<0.05)$ & Yes \\
\hline One- or two-tailed $p$ value? & Two-tailed \\
\hline
\end{tabular}

$\square$ Control (12)

$\square$ RKW-A (10)

$\square$ RKW (9)

$\square \mathrm{EGC}(8)$

Fig. 6. bFGF concentration in the sera from: control mothers, mothers fed $R$. kirilowii aqueous extract (RKW), hydro-alcoholic extract (RKW-A), or epigallocatechin (EGC). Number of mice in parentheses 
found equal proportions of those compounds. Some of them exist in proportional concentration (e.g salidroside, kaempferol) and some in reverse proportions (e.g. ellagic acid or (+)-catechin). The probable mechanism may be connected with bioavailability (absorption from the gastrointestinal tract with possible competition for receptors or formation of conjugates, which will not be absorbed) or biodistribution (change of solubility/affinity by addition of glucoronid, sulfate or other groups; increased absorption in some tissues and organs or increased utilization).

In our research, sera of mice fed during pregnancy and lactation Rhodiola kirilowii extracts contained higher concentration of VEGF (RKW-A) and bFGF (both of them) than corresponding controls. Despite of this, we observed antiproliferative activity of sera from mothers fed a hydro-alcoholic extract. This might be associated with a higher, than in mice fed a water extract, serum content of strongly anti-angiogenic substances (salidroside and catechins). Confirmation of anti-angiogenic properties of above polyphenols we obtained in our previous studies on embryonic and tumor angiogenesis in mice [10, 20, 21]. Also Sun et al. [22] showed anticancer effect of salidroside on colon cancer through inhibiting JAK2/STAT3 signaling pathway. In addition Wang et al. [23] demonstrated anticancer effect of salidroside on A549 lung cancer cells through inhibition of oxidative stress and phospho-p38 expression.

Analysed murine blood sera samples showed differences in concentrations of polyphenols, which resulted from supplementation of mice diet with various sources of these compounds. Differences between groups RKW and RKW-A were probably caused by using two different extraction methods to extract polyphenols from Rhodiola kirilowii. Previous reports have demonstrated that the differences in extraction efficiency are observed mainly in the case of $(+)$-catechin, p-coumaric acid and naringenin [1]. In the present study sera samples of mother mice from group RWK contained the highest concentration of (+)-catechin when compared with the other groups. Alcohol (RKW-A) extract with significantly higher (+)-catechin, epicatechin and epigallocatechin content did not cause a significant increase in the concentration of these compounds in the serum, except epicatechin. On the contrary water Rhodiola kirilowii extract significantly augmented the plasma level of catechins, except epigallocatechin. These observations are not easy to interpret. It is possible, that such effect could be observed due to the analytical method used in this study. Enzymatic hydrolysis conducted during samples preparation for chromatographic analyses aimed to change the glycosidic polyphenols to aglycone forms of these compounds, which could cause accumulation of catechins in the samples. It is also possible that the hydro-alcoholic Rhodiola kirilowii extract provides organism with more accessible polyphenol forms - aglycones, which are easier to absorb, thus the metabo- lisms and excretion may be faster [24]. To verify this hypothesis future experiments should include urine 24-hour volume test and examination of catechins concentration in such samples. Furthermore, in the present study epicatechin and epigallocatechin serum concentrations were the highest in mice receiving diet supplemented with epigallocatechin. High content of pure epigallocatechin in the diet influenced the levels of epigallocatechin and epicatechin (its derivative with lower molecular mass) detected in the serum. Metabolism of these catechins includes lowering of the molecular mass during distribution with blood and metabolism in the liver. Conjugation with glucuronic acid enables their fast excretion from the organism [25]. Although results obtained ambiguously explain the relationship between the type of dietary supplementation with polyphenolic compounds and their serum concentration, the effect of polyphenols on the organism of mother mice was definitely observed, and was significant with reference to investigated parameters.

\section{Conclusions}

These data allow to assume that Rhodiola kirilowii hydro-alcoholic extract (RKW-A) is potentially able to modulate pre- and post-natal angiogenesis what might influence the development of organs in progeny. Sera of RKW mothers have not harm the proliferation of endothelial cells, despite they also contain antiangiogenic catechins and salidroside. Sera collected from mothers supplemented with epigallocatechin also have not influenced endothelial cells proliferation, despite the highest content of epicatechin and epigallocatechin. This might suggest the existence in RKW-A extract and in RKW-A sera some other, yet unidentified substances influencing endothelial cells proliferation.

It remains to be considered the possibility also that salidroside in lower concentration stimulates the migration of endothelial cells, and in higher inhibits endothelial cell proliferation.

The present study was supported by the National Centre of Science (Kraków, Poland; grant no. 2012/05/B/NZ 7/03219).

The authors declare no conflict of interest.

\section{References}

1. Zdanowski R, Lewicki S, Sikorska K, et al. (2014): The influence of aqueous and hydro-alcoholic extracts of roots and rhizomes of Rhodiola kirilowii on the course of pregnancy in mice. Cent Eur J Immunol 39: 471-475.

2. Radomska-Leśniewska D, Skopiński P, Bałan BJ, et al. (2015): Angiomodulatory properties of Rhodiola spp. and other natural antioxidants. Cent Eur J Immunol 40: 249-262. 
3. Siwicki AK, Skopinska-Różewska E, Hartwich M, et al. (2007): The influence of Rhodiola rosea extracts on non-specific and specific cellular immunity in pigs, rats and mice. Cent Eur J Immunol 32: 84-91.

4. Wójcik R, Siwicki AK, Skopińska-Różewska E, et al. (2009): The effect of Chinese medicinal herb Rhodiola kirilowii extracts on cellular immunity in mice and rats. Pol J Vet Sci 12: 399-405.

5. Skopinska-Różewska E, Bychawska M, Białas-Chromiec B, Sommer E (2009): The In vivo effect of Rhodiola rosea and Rhodiola quadrifida hydro-alcoholic extracts on chemokinetic activity of spleen lymphocytes in mice. Centr Eur J Immunol 34: 42-45.

6. Skopińska-Różewska E, Bychawska M, Białas-Chromiec B, et al. (2010): The in vivo effect of Rhodiola kirilowii extracts on blood granulocytes metabolic activity in mice. Cent Eur J Immunol 35: 20-24.

7. Siwicki A, Skopińska-Różewska E, Wasiutyński A, et al. (2012): The effect of Rhodiola kirilowii extracts on pigs blood leukocytes metabolic (RBA) and proliferative (LPS) activity, and on the bacterial infection and blood leukocytes number in mice. Centr Eur J Immunol 37: 145-150.

8. Zdanowski R, Lewicki S, Skopińska-Różewska E, et al. (2014): Alcohol- and water-based extracts obtained from Rhodiola rosea affect differently the number and metabolic activity of circulating granulocytes in Balb/c mice. Ann Agric Environ Med 21: 120-123.

9. Skopinska-Różewska E, Hartwich M, Siwicki AK, et al. (2008): The influence of Rhodiola rosea extracts and rosavin on cutaneous angiogenesis induced in mice after grafting of syngeneic tumor cells. Centr Eur J Immunol 33: 102-107.

10. Skopińska-Różewska E, Malinowski M, Wasiutyński A, et al. (2008): The influence of Rhodiola quadrifida $50 \%$ hydro-alcoholic extract and salidroside on tumor-induced angiogenesis in mice. Pol J Vet Sci 11: 97-104.

11. Zdanowski R, Skopinska-Różewska E, Wasiutyński A, et al. (2012): The effect of Rhodiola kirilowii extracts on tumor-induced angiogenesis in mice. Centr Eur J Immunol 37: 131-139.

12. Lewicki S, Stankiewicz W, Skopińska-Różewska E, et al. (2015): Spleen content of selected polyphenols, splenocytes morphology and function in mice fed Rhodiola kirilowii extracts during pregnancy and lactation. Pol J Vet Sci 18: 847855.

13. Shin JW, Seol IC, Son CG (2010): Interpretation of animal dose and human equivalent dose for drug development. J Korean Oriental Med 31: 1-7.

14. Bizouarne N, Denis V, Legrand A, et al. (1993): A SV-40 immortalized murine endothelial cell line from peripheral lymph node high endothelium expresses a new alpha-L-fucose binding protein. Biol Cell 79: 209-218.

15. Kieda C, Paprocka M, Krawczenko A, et al. (2002): New human microvascular endothelial cell lines with specific adhesion molecule phenotypes. Endothelium 9: 247-261.

16. Skopiński P, Zdanowski R, Grzela T, et al. (2012): The influence of sterilized and non-sterilized amniotic dressings on the proliferation of endothelial cells in vitro. Cent Eur J Immunol 37: 114-118.

17. Rokicki D, Zdanowski R, Lewicki S, et al. (2014): Inhibition of proliferation, migration and invasiveness of endothelial murine cells culture induced by resveratrol. Cent Eur J Immunol 39: 449-454.
18. Irchhaiya R, Kumar A, Yadav A, et al. (2014): Metabolites in plants and its classification. World J Pharm Pharmac Sci 4: $287-305$

19. Zhou T, Zheng J, Zhou Y, et al. (2015): Chemical Components and Bioactivities of Rhodiola rosea. Int J Trad Nat Med 5: 23-51.

20. Skopiński P, Skopińska-Różewska E, Kamiński A, et al. (2004): Chocolate feeding of pregnant mice resulted in epigallocatechin- related embryonic angiogenesis suppression and bone mineralization disorder. Pol J Vet Sci 7: 131-133.

21. Wasiutyński A, Siwicki AK, Bałan BJ, et al. (2005): Inhibitory effect of cocoa catechins on embryonic and tumor angiogenesis in mice. Pol J Environm Studies 14: 800-805.

22. Sun KX, Xia H, Xia RL (2015): Anticancer effect of salidroside on colon cancer through inhibiting JAK2/STAT3 signaling pathway. Int J Clin Exp Pathol 8: 615-621.

23. Wang J, Li JZ, Lu AX, et al. (2014): Anticancer effect of salidroside on A549 lung cancer cells through inhibition of oxidative stress and phospho-p38 expression. Oncol Lett 7: 1159-1164.

24. Liang J, Xu F, Zhang YZ, et al. (2014): The profiling and identification of the metabolites of (+)-catechin and study on their distribution in rats by HPLC-DAD-ESI-IT-TOF-MS(n) technique, Biomed Chromatogr 28: 401-411.

25. Blount JW, Redan BW, Ferruzzi MG, et al. (2015): Synthesis and quantitative analysis of plasma-targeted metabolites of catechin and epicatechin, J Agric Food Chem 63: 2233-2240. 